\title{
WestVirginiaUniversity
}

THE RESEARCH REPOSITORY @ WVU

Volume 27 | Issue 3

Article 12

March 1921

\section{Gifts--Choses in Action--Delivery}

A. W. L.

West Virignia University College of Law

Follow this and additional works at: https://researchrepository.wvu.edu/wvlr

Part of the Estates and Trusts Commons

\section{Recommended Citation}

A. W. L., Gifts--Choses in Action--Delivery, 27 W. Va. L. Rev. (1921).

Available at: https://researchrepository.wvu.edu/wvlr/vol27/iss3/12

This Recent Case is brought to you for free and open access by the WVU College of Law at The Research Repository @ WVU. It has been accepted for inclusion in West Virginia Law Review by an authorized editor of The Research Repository @ WVU. For more information, please contact ian.harmon@mail.wvu.edu. 
bethtown, 275 Ill. 167, 114 N. E. 14; City of Miami v. Florida etc. Co., 84 So. 726 (Fla.). The principal case, which is the first case in which the West Virginia court has been called upon to decide this question, seems to have definitely adopted the latter view. In those states where the rule of the principal case on this point is followed, the courts are not agreed as to the extent of acceptance necessary to make the dedication irrevocable. Some hold that an acceptance of one or more of the streets shown on the plat is an acceptance of all, unless a contrary intention be clearly shown. Village of Lee v. Harris, 206 Ill. 428, 69 N. E. 230; Caruthersville v. Huffman, 262 Mo. 367, 171 S. W. 323. Others hold that the dedicator may revoke the dedication as to those streets not actually accepted. Moore v. City of Chicago, 261 Ill. 56, 103 N. E. 583; Kennedy v. Mayor, etc. of Cumberland, 65 Mr. 514, 9 Atl. 234. See 3 Dillon, Municipal Corporations, 5 ed., 1734-1735. If the plat is considered as an offer on the part of the landowner to dedicate all the streets, etc., shown thereon as an entirety, it would seem logically to follow that the acceptance must be of the whole. Inasmuch, however, as this might impose undue burdens upon the municipality, without correspondingly benefiting anybody, it is thought that the doctrine of the principal case is the better view.

-W. F. K.

Gifts-Choses in Action-Delivery.-A father, by his will, gave a farm to his four younger sons. The farm was subject to a lien debt, which was evidenced by four bonds, and the four sons were to take the farm charged with such lien debt. During his lifetime the father paid certain of the bonds which had become due and told the sons, in conference, that they owed him the sum which he had paid. They tendered a check in payment, but he did not accept. He told them to pay the money to their two married sisters. The father died, and the question' was whether the two married sisters could obtain the sum which the father had paid on the bonds. Held, they could not, but such sum should be paid to the father's estate. Poff v. Poff, 104 S. E. 719 (Va. 1920).

The general lezal principle regulating gifts of personalty is that mere words of donation will not suffice to pass title. Stratton v. Athol Savings Bank, 213 Mass. 46, 99 N. E. 454. With 
regard to chattels, there must be an actual delivery of possession or a deed of gift. Barnes v. Banks, 223 Ill. 352; Ross v. Milne, 12 Leigh 204 (Va.); Connor v. Trawick, 37 Ala. 289. The same rule applies to gifts of choses in action represented by a specialty; and the delivery of such specialty must amount to a transfer of all the donor's control or dominion over the subject. In some cases where actual delivery of a chattel cannot be made, resort may be had to what has been called a symbolical delivery. White v. Kilgore, 77 Me. 571. A chose in action not represented by a specialty cannot be physically transferred. It has been held, therefore, that such a chose in action cannot be given away irrevocably. Cook v. Lum, 55 N. J. L. 373. However, an. equitable chose in action, which is just as intangible, and delivery of which is just as impossible, may be given away without any formalities other than an expression of intent. Harding v. Harding, 17 Q. B. D. 442 ; Wilt v. Hoffman, 46 W. Va. 473 , 33 S. E. 279. There seems to be no good reason for the distinction which exists between legal and equitable choses in action. The principal case is concerned with a legal chose, and is in accord with the settled law, but it would seem that such decision might be argued to be wrong on principle.

-A. W. L.

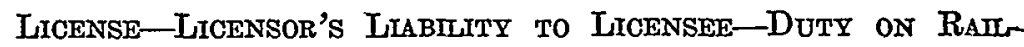
ROAD COMPanY.-Plaintiff, an adult, not in the employ of the railroad company, was struck by a backing train and killed, while using a railroad track as a footpath for his own convenience elsewhere than at a public crossing. Two problems: were presented. First, whether the railroad company had any duty to look out for the plaintiff. Second, whether the railroad company owed a duty after perceiving the plaintiff to do more than refrain from the infliction of wanton or wilful injury. Held, there was no duty to look out for plaintiff, but after he was discovered there was a duty on the defendant to use reasonable care to avoid injuring him. Robertson v. Coal \& Coke R. Co., 104 S. E. 615 (W. Va. 1920).

It is settled that the owner is under no duty to a bare licensee to keep the premises in safe condition. Plummer v. Dul, 156 Mass. 426, 31 N. E. 128 . There is no commonly accepted rule in this country as to the duty of a railroad company to keep a 